\title{
Effects of Dietary Inclusion of Pentadiplandra brazzeana Powder on Growth Performances, Gut Microbiota, and Haemato-Biochemical Indices of Broiler Chickens
}

\author{
Necdem Tsafack Boris*, Kana Jean Raphaël, Ngouana Tadjong Ruben, Ebile Dayan Agwah, Donfack Mikael, \\ Tchouan Deffo Gilchrist and Kengni Noubissie Josiane
}

Animal production and Nutrition Research Unit, Department of Animal sciences, Faculty of Agronomy and Agricultural Sciences, University of Dschang, Cameroon.

*Corresponding author's Email: borisnecdem@yahoo.fr; (DORCID: 0000-0002-7660-7867

\begin{abstract}
This study was designed to assess the rearing performances of broiler chickens under two Pentadiplandra brazzeana powder feeding diets. A total of 256 day-old Cobb 500 broiler chicks were randomly assigned to 4 treatment groups with 4 replicates of 16 birds each in a completely randomized design. This trial involved administrating Pentadiplandra brazzeana powder to broiler chickens via drinking water $(2 \mathrm{~g} / \mathrm{l})$ or dry feed $(2 \mathrm{~g} / \mathrm{kg})$ and comparing the result to those obtained from chickens fed on antibiotic $(1 \mathrm{~g} / \mathrm{kg})$ and chickens fed without additive. The results revealed that the incorporation of Pentadiplandra brazzeana powder in chickens' diet and drinking water could decrease feed intake, compared to the negative control diet. The inclusion of Pentadiplandra brazzeana powder in water and antibiotic in diet recorded the high live weight and weight gain, compared to the birds fed with the powder in feed and the negative control diet. The low feed conversion ratio was reported with the water supplemented with P. brazzeana powder. The carcass yield was significantly higher with the inclusion of the powder via drinking water, compared to the inclusion via feed and with the control diet. The feeding method did not affect the haematobiochemical parameters, compared to the control diet. Chickens fed with a diet containing Pentadiplandra brazzeana powder in water recorded the highest $(\mathrm{p}<0.05)$ lactic acid bacteria count, compared to $E$. coli and Salmonella. In conclusion, dietary supplementing with Pentadiplandra brazzeana powder through drinking water at a rate of $2 \mathrm{~g} / \mathrm{l}$ can be used as an alternative to antibiotics to improve the growth performances of broiler chickens.
\end{abstract}

Keywords: Broiler chicken, Growth performances, Gut microflora, Haemato-biochemical profile, Pentadiplandra brazzeana

\section{INTRODUCTION}

The use of Antibiotic Growth Promoters (AGPs) in animal diet has led not only to the development of resistance by pathogenic bacteria (Toghyani et al., 2011), but also residues found in livestock products could be harmful for consumer health (Vicente et al., 2007). It has been resulted to the systematic interdiction and removal of AGPs in animal nutrition (Cervantes, 2006, Kana et al., 2017a). Therefore, the searches for alternative feed supplements have been increased extensively and considerable attention has been given to phytogenic as replacements for antibiotics growth promoters, which should have the same beneficial effect as AGPs. Phytobiotic or phytogenic are compounds of plant origin which are incorporated in animal feed to improve growth performances through their anti-oxidative and antimicrobial action (Oko and Agiang, 2009; Gakunga et al., 2013; Alonge et al., 2017). Example of some phytobiotics includes herbs, spices as well as extracts of plants (Windisch et al., 2008). The beneficial properties of phytobiotic is due to the presence of actives substances such as phenol, tannins, alkaloids and terpenoïds (Alloui et al., 2011). These actives substances in animal industry, have the ability to activate feed intake and digestive secretion, anti-inflammatory activity, antimicrobial and antioxydant properties. Previous study revealed that Zingiber officinale and Allium sativum (Karangiya et al., 2016), Tetrapleura tetraptera, Afrostyrax lepidophyllus and Dichrostachys glomerata improve growth performance of broiler chickens (Kana et al., 2017abc).

Pentadiplandra brazzeana is a spontaneous arborescent shrub or climber growing from the West coast of Africa, Central Africa to the basin of the Zambezi (Kouka, 2001). This species is widely used in traditional medicine. The roots of these plants are often harvested by the local people to treat many types of ailments such as kidney pains and hemorrhoids, constipation, cough and post-partum hemorragy (Cimanga et al., 2018; Lautenschläger et al., 2018). These supplements are commonly used for their culinary properties (Abdou et al., 2012). Phytochemical test of the roots has revealed the presence of alkaloids, flavonoids, tannins, phenols and triterpernes (Ngbolua et al., 2011; Lautenschläger et al., 2018). Also, in vitro studies have revealed antimicrobial (Nyegue et al., 2009), antifungic (Dzoyem et al., 2014), 
antioxidant (Abdou et al., 2012) and cytotoxic (Kuete et al., 2011) properties of the roots of this plant. Based on these properties, it's proposed that roots of this plant, commonly use as spice could balance the gut microbiata, ensure good health, thus improving growth performances of broiler chickens. However, the active compounds present in this spice are easily damageable, which can prevent adequate levels from reaching target sites and lead to a decrease of the potential bioactivity of these compounds, a qualitative loss of properties (Mahmood et al., 2018), thus reducing the effectiveness of the powder. Hence, the need to find a way of administrating of the spice powder through the diet, making it possible to better conserve and limit the alteration of its active compounds in order to make them more available and accessible along the digestive tract of the animal. So, the aim of this study was to evaluate the effects of Pentadiplandra brazzeana powder either in water or in feed supplement on growth performances in order to determine the best way of incorporating spices powder in poultry diet.

\section{MATERIALS AND METHODS}

\section{Ethical approval}

The present study has been performed in agreement with the guidelines of the ethical standards from the 1964 Helsinki declaration and latterly amendment under approval code \# CU/II/F/34/19\#.

\section{Conditions of experiment}

The study was carried out at the Teaching and Research Farm of the Faculty of Agronomy and Agricultural Sciences, University of Dschang, Cameroon. Annual temperatures vary between $10^{\circ} \mathrm{C}$ and $25^{\circ} \mathrm{C}$.

\section{Feed additives}

Dried sample of Pentadiplandra brazzeana roots was ground into powder in a harmed mill, sieved and incorporated in the experimental diets. Sample of the ground spices was put into polyethylene plastics and stored at $4{ }^{\circ} \mathrm{C}$ in a refrigerator until analysis. Phytochemical screening of Pentadiplandra brazzeana was done according to the common phytochemical methods described by Harborne (1973). The screening revealed that saponins and sterols were absent. Phenols, tannins, flavonoids alcaloids, tripernoids, anthocyanins and anthraquinons tests were positive. Antibiotic (Doxycyclin ${ }^{\circledR}$ ) used in the positive control diet was bought from a local veterinary pharmacy.

\section{Animal and experimental diets}

A total of 256 day-old Cobb 500 broiler chicks were randomly assigned to four treatments groups in a completely randomized design with 64 birds per treatment. Each group was sub divided into 4 replicates of 16 birds each. Two experimental diets were formulated from the negative control diet ( $\mathrm{T}^{-}$) formulated to meet their requirements (table 1) by incorporating $1 \mathrm{~g}$ of antibiotic/kg of feed and considered as positive control diet (T0+) and $2 \mathrm{~g}$ of $P$. brazzeana powder/kg of feed (T1). The last treatment consisted of incorporating $2 \mathrm{~g}$ of $P$. brazzeana powder in drinking water (T2). Throughout the experiment, vaccination and other routine poultry management practices were maintained. Chicks were weighed at the beginning of the experiment and on a weekly basis thereafter. Data on feed intake (FI) and body weight gain (BWG) were estimated and use to calculate feed conversion ratio (FCR). Feed and water were offered ad libitum.

\section{Sample collection and analysis}

Growth performances, hematological and serum biochemical parameters

Feed intake, weight gain and feed conversion ratio were evaluated on a weekly basis in both starter and finisher phases of the study. At the end of the feeding trial (49 days of age), 10 birds ( 5 males and 5 females) from each treatment group were randomly selected, fasted for 24 hours and slaughtered for carcass evaluation as preceded by Kana et al. (2017). From each slaughtered bird, blood was collected in 2 test tubes, one of which contained as anticoagulant. Blood with anticoagulant was used for hematological analysis using a full automatic blood cell counter (model PCE-210N Hong kong, china). Hematological parameters included White blood cell (WBC), Red blood cell (RBC), Hemoglobin (Hgb), Mean cell hemoglobin concentration (MCHC), Mean cell volume (MCV), Mean cell hemoglobin (MCH) and Packed cell volume (PCV). Meanwhile, after centrifugation of blood free from anticoagulant, serum was collected and preserved at $-20^{\circ} \mathrm{C}$ for the evaluation of total protein, albumin, globulin, aspartate aminotransferase (ASAT), alanine aminotransferase (ALAT), total cholesterol, high density lipoproteins (HDL), low density lipoprotein (LDL), triglyceride, urea and creatinine, using the colorimetric method as prescribed by the commercial kits (Spinreact $®$ kits).

\section{Microbial count}

A sterile spatula was used to collect freshly bird feces through cloacal swab. The identification and quantification of bacteria were assessed on appropriate specific culture media (MRS Agar for lactic acid bacteria, Mac conkey Agar for E. coli, SS Agar for Salmonella). Samples were incubated at $37^{\circ} \mathrm{C}$ for $24 \mathrm{~h}$. 


\section{Statistical analysis}

Data recorded on growth, hematological, biochemical and microbial parameters were submitted to one-way analysis of variance test by the general linear model procedure of statistical package for Social Science (SPSS ver. 20.0) software. The differences were tested using Duncan test and probability values less than 0.05 was considered as significant (Steel and Torrie, 1980).

Table 1. Composition and chemical analysis of basal diet

\begin{tabular}{lcc}
\hline Ingredients (\%) & Starter (0-21d) & Finisher (22-49d) \\
\hline Maize & 60 & 68 \\
Wheat bran & 3 & 2 \\
Soybean meal & 21 & 14 \\
Cotton seed meal & 5 & 5 \\
Fish meal & 5 & 5 \\
Oeister shell & 1 & 1 \\
Premix 5\%* & 5 & 5 \\
Total & 100 & 100 \\
\hline Chemical analysis & & \\
Metabolizable energy (Kcal/kg) & 2895.04 & 2998.50 \\
Crude protein (\%) & 21.58 & 19.29 \\
Energy/protein & 134.15 & 155.68 \\
Calcium (\%) & 1.17 & 1.15 \\
Phosphorous (\%) & 0.48 & 0.44 \\
Calcium/phosphorous & 2.37 & 2.60 \\
Lysin (\%) & 1.37 & 1.15 \\
Methionin (\%) & 0.48 & 0.44 \\
Lysin/methionin & 2.85 & 2.63 \\
Crude fibre (\%) & 5.00 & 5.19 \\
\hline Premix 5\%: crude proteins 400 mg, Lysin 33 mg, Methionin 24 mg, Calcium 80 mg, Phosphorous $20.5 \mathrm{mg}$, metabolizable energy $2078 \mathrm{kcal} / \mathrm{kg}$, \\
Vitamins: Retinol 10 000 000 IU, Cholecalciferol 3 000 000 UI, Tocopherol 2500 IU, Phylloquinon 4000 mg, Thiamin 5000 mg, Riboflavin 500 mg, \\
Pyridoxin 2500 mg, Cyanocobalamin 5 mg, Folic acid 10 000 mg and Niacin 2000 mg.
\end{tabular}

\section{RESULTS AND DISCUSSION}

\section{Growth performances}

Table 2 indicated the effect of the feeding mode of $P$. brazzeana powder on growth performances. During the growing phase and throughout the production period, the administration of $P$. brazzeana powder through feed and water induced a significant $(\mathrm{p}<0.05)$ decrease in feed intake compared to the negative control diet. This decrease in feed intake could be explained by the strong smell of the spice and the presence of alkaloids which may have induced a bitter taste and have not been well appreciated by the birds inducing the drop of the consumption. These results are in agreement with the finding of Kana et al. (2017c) who reported that administration of Tetrapleura tetraptera powder in broiler chickens feed significantly decreased feed intake. The present result is in contradiction with the finding of Nweze et al. (2011) who reported that feeding broilers with Tetrapleura tetraptera through feed, fresh and boiled water has no effect on feed intake. Similarly, Kana et al. (2017b) recorded no significant effect on feed intake with the incorporation of $2 \mathrm{~g}$ of Afrostyrax lepidophyllus fruit and bark powder in broilers feed. Likewise, Ebile et al. (2018a) reported that feeding quails with $0.5 \%$ of Dichostachys glomerata powder through feed or water had no significant effects $(\mathrm{p}<0.05)$ on feed intake. The difference between all these results can be attributed to the variability of composition in actives compounds in those spices.

As shown in table 2, birds fed on antibiotic and P. brazzeana powder in drinking water recorded the highest live weight and weight gain $(\mathrm{p}<0.05)$ compared to the negative control and birds receiving $P$. brazzeana powder through feed. These decreased due to the administration through feed of the spice powder could be explained by a loss of some active ingredients in the feed due to their volatility. This reduction of growth is similar to the finding of Kana et al. (2017c) who reported that during the brooding phase diet supplemented with Tetrapleura tetraptera powder decreased live body weight. In contrary, the highest body weight obtained with water administration could be explained by the effectiveness of water in extracting secondary metabolites from the spice and made it more disponible for the animal. These active metabolites have antibacterial and antioxidant properties known to reduce the risk of developing microbiota pathogens, by destroying the bacterial membranes, making unavailable certain substrates for the bacteria and inactivate bacterial enzyme (Windisch et al., 2008), resulting in greater availability of certain nutrients, thus improving in live weight. This result is similar to those of Vivian et al. (2015) who reported that the aqueous extract of ginger significantly improved growth performances of chickens.

Data presented in table 2 showed that, birds receiving antibiotic and P. brazzeana powder through water recorded the lowest $(p<0.05)$ FCR of all the treatments. This decrease in FCR can be understood by a greater availability of active ingredients in water than in feed, due to their antibacterial, anti-inflammatory and anti-oxidant properties improved the availability and increased the absorption and better utilization of nutrients. 
The effects of $P$. brazzeana feeding diets on carcass yield and relative weight of organs are presented in table 3. Regardless of $P$. brazzeana feeding diets, there were no significant ( $\mathrm{p}>0.05$ ) effects on relative weight of the legs, heart, liver, gizzard and abdominal fat compared to the control diets. Bird fed with antibiotic and P. brazzeana powder in drinking water recorded the highest $(\mathrm{p}<0.05)$ carcass yield compared to the negative control and the administration of the powder through feed. This improvement of carcass yield may result in the positive effect on live weight. These results are in contradiction with those of Kana et al. (2017c) who reported no significant effect on carcass yield when birds were fed with Tetrapleura tetraptera powder.

Table 2. The effects of $P$. brazzeana diets in growth performance of broilers

\begin{tabular}{|c|c|c|c|c|c|c|}
\hline \multirow{2}{*}{ Characteristics } & \multirow{2}{*}{$\begin{array}{l}\text { Study period } \\
\text { (days) }\end{array}$} & \multicolumn{5}{|c|}{ Treatments } \\
\hline & & T0- & $\mathrm{TO}^{+}$ & $\mathrm{T} 1$ & T2 & $P$ \\
\hline \multirow{3}{*}{ Feed intake (g) } & $01-21$ & $1152.50 \pm 29.41^{\mathrm{a}}$ & $1014.94 \pm 76.05^{\mathrm{b}}$ & $1089.03 \pm 64.40^{\mathrm{ab}}$ & $1135.55 \pm 35.69^{\mathrm{a}}$ & 0.01 \\
\hline & $22-49$ & $4152.40 \pm 63.88^{\mathrm{a}}$ & $4024.47 \pm 74.58^{\mathrm{b}}$ & $4026.84 \pm 70.96^{\mathrm{b}}$ & $4005.97 \pm 25.92^{\mathrm{b}}$ & 0.02 \\
\hline & $1-49$ & $5304.90 \pm 46.68^{\mathrm{a}}$ & $5039.40 \pm 37.54^{\mathrm{c}}$ & $5115.37 \pm 75.78^{\mathrm{b}}$ & $5141.53 \pm 21.56^{\mathrm{b}}$ & 0.00 \\
\hline \multirow{2}{*}{ Live weight (g) } & $01-21$ & $636.73 \pm 24.00^{\mathrm{a}}$ & $583.31 \pm 26.74^{\mathrm{b}}$ & $574.78 \pm 35.08^{b}$ & $635.90 \pm 21.26^{\mathrm{a}}$ & 0,01 \\
\hline & $22-49$ & $2146.26 \pm 17.02^{\mathrm{b}}$ & $2281.52 \pm 24.60^{\mathrm{a}}$ & $2114.38 \pm 27.21^{\mathrm{b}}$ & $2270.30 \pm 25.51^{\mathrm{a}}$ & 0,00 \\
\hline \multirow{3}{*}{$\begin{array}{l}\text { Body weight gain } \\
\text { (g) }\end{array}$} & $01-21$ & $596.73 \pm 24.00^{\mathrm{a}}$ & $543.31 \pm 26.74^{\mathrm{b}}$ & $552.28 \pm 25.20^{\mathrm{b}}$ & $595.64 \pm 17.37^{\mathrm{a}}$ & 0.01 \\
\hline & $22-49$ & $1518.39 \pm 23.66^{\mathrm{b}}$ & $1698.27 \pm 24.70^{\mathrm{a}}$ & $1580.43 \pm 45.40^{\mathrm{b}}$ & $1643.51 \pm 27.75^{\mathrm{a}}$ & 0.00 \\
\hline & $01-49$ & $2115.12 \pm 21.11^{\mathrm{b}}$ & $2241.58 \pm 20.15^{\mathrm{a}}$ & $2082.54 \pm 54.60^{\mathrm{b}}$ & $2239.15 \pm 42.52^{\mathrm{a}}$ & 0.00 \\
\hline \multirow{3}{*}{$\begin{array}{l}\text { Feed conversion } \\
\text { ratio }\end{array}$} & $01-21$ & $1.93 \pm 0.05$ & $1.87 \pm 0.18$ & $1.96 \pm 0.17$ & $1.91 \pm 0.09$ & 0.11 \\
\hline & $22-49$ & $2.69 \pm 0.04^{\mathrm{a}}$ & $2.37 \pm 0.06^{\mathrm{c}}$ & $2.54 \pm 0.11^{\mathrm{b}}$ & $2.40 \pm 0.05^{\mathrm{c}}$ & 0.00 \\
\hline & $01-49$ & $2.48 \pm 0.02^{\mathrm{a}}$ & $2.22 \pm 0.02^{\mathrm{c}}$ & $2.37 \pm 0.09^{\mathrm{b}}$ & $2.27 \pm 0.05^{\mathrm{c}}$ & 0.00 \\
\hline
\end{tabular}

$\overline{\mathrm{a}, \mathrm{b}}$ : Means with the same superscript on the same row are not significantly different $(\mathrm{p}>0,05) . \mathrm{P}=$ probability. $\mathrm{T} 0^{-}=$control diet; $\mathrm{T} 0^{+}=\mathrm{T} 0+0.1 \%$ Doxycycline; $\mathrm{T} 1=\mathrm{T} 0+2 \mathrm{~g}$ of $P$. brazzeana $/ \mathrm{kg}$ of feed; $\mathrm{T} 2=\mathrm{T} 0+2 \mathrm{~g}$ of $P$. brazzeana /iter of water.

Table 3. The effects of $P$. brazzeana diets in carcass characteristics of broiler chickens

\begin{tabular}{lccccc}
\hline \multirow{2}{*}{ Parameters $(\% \mathbf{B W})$} & \multicolumn{3}{c}{ Treatments } & \multicolumn{1}{c}{ T2 } & P1 \\
\cline { 2 - 6 } & T0 $^{-}$ & T0+ & $71.59 \pm 1.67^{\mathrm{b}}$ & $74.12 \pm 1.70^{\mathrm{a}}$ & 0.00 \\
Carcass yield & $72.18 \pm 1.84^{\mathrm{b}}$ & $74.54 \pm 1.84^{\mathrm{a}}$ & $2.12 \pm 0.23^{\mathrm{b}}$ & $2.27 \pm 0.24^{\mathrm{b}}$ & 0.00 \\
Head & $2.50 \pm 0.14^{\mathrm{a}}$ & $2.27 \pm 0.16^{\mathrm{b}}$ & $3.59 \pm 0.52$ & $3.83 \pm 0.34$ & 0.12 \\
Leg & $3.55 \pm 0.33$ & $3.88 \pm 0.47$ & $1.94 \pm 0.28^{\mathrm{b}}$ & $1.68 \pm 0.42^{\mathrm{b}}$ & 0.00 \\
Liver & $1.79 \pm 0.12^{\mathrm{b}}$ & $2.35 \pm 0.45^{\mathrm{a}}$ & $0.18 \pm 0.04$ & $0.16 \pm 0.03$ & 0.61 \\
pancreas & $0.17 \pm 0.03$ & $0.16 \pm 0.02$ & $1.58 \pm 0.21$ & $1.45 \pm 0.13$ & 0.72 \\
Gizzard & $1.48 \pm 0.18$ & $1.52 \pm 0.25$ & $0.42 \pm 0.06$ & $0.45 \pm 0.10$ & 1.05 \\
Heart & $0.46 \pm 0.07$ & $0.48 \pm 0.08$ & $2.79 \pm 0.69$ & $2.30 \pm 0.41$ & 1.46 \\
Abdominal fat & $2.48 \pm 0.50$ & $2.44 \pm 0.54$ & &
\end{tabular}

${ }^{\mathrm{a}, \mathrm{b}}$ : Means with the same superscript on the same row are not significantly different $(\mathrm{p}>0.05) . \mathrm{P}=$ probability. $\mathrm{T} 0^{-}=$control diet; $\mathrm{T} 0^{+}=\mathrm{T} 0+0.1 \%$ Doxycycline; $\mathrm{T} 1=\mathrm{T} 0+2 \mathrm{~g}$ of $P$. brazzeana $/ \mathrm{kg}$ of feed; $\mathrm{T} 2=\mathrm{T} 0+2 \mathrm{~g}$ of $P$. brazzeana /iter of water.

\section{Gut microbiata}

As shown in table 4, the analysis of variance revealed that, the number of Escherichia coli and salmonella was significantly lower with the administration of antibiotic and P. brazzeana powder through feed and water compared to the negative control diet. Thus, as non-significant, the number of these pathogenic bacteria was less in birds receiving the spice through water compared to feed. This could be explained by the presence of active substances like phenols, flavonoid and alkaloids in the spice which promoted the development of lactic acid bacteria by reducing the development of pathogeneous bacteria. Antimicrobial property of the spice is considered to arise from phenols (Muanda et al., 2011), and hydrophobic compounds present in spices that intrude into the bacterial cell membrane inducing the disintegration of the membrane structure and cause leakage thus making microbes less virulent (Windisch et al., 2008). This result are in agreement with the findings of Ngouana et al. (2017) who observed an increased in lactic acid bacteria population in the intestine of healthy chickens. The lactic acid bacteria multiply and eliminate pathogenic bacteria by acidifying the intestinal gut and producing antibacterial substances like organic acids (Elarousi et al., 2008).

Table 4. Fecal microbial load of broiler chickens as affected P. brazzeana diets

\begin{tabular}{lccccc}
\hline Bacteria load log10 & \multicolumn{5}{c}{ Treatments } \\
\cline { 2 - 6 } (UFC) & T0 $^{-}$ & T0+ & T1 & T2 & P \\
\hline Lactobacillus spp & $8.65 \pm 0.14^{\mathrm{ab}}$ & $8.42 \pm 0.17^{\mathrm{b}}$ & $8.51 \pm 0.16^{\mathrm{ab}}$ & $8.60 \pm 0.16^{\mathrm{a}}$ & 0.05 \\
Escherichia. coli & $8.91 \pm 0.09^{\mathrm{a}}$ & $8.47 \pm 0.08^{\mathrm{b}}$ & $8.64 \pm 0.20^{\mathrm{b}}$ & $8.42 \pm 0.11^{\mathrm{b}}$ & 0.00 \\
Salmonella spp & $8.69 \pm 0.12^{\mathrm{a}}$ & $8.35 \pm 0.07^{\mathrm{b}}$ & $8.50 \pm 0.10^{\mathrm{b}}$ & $8.42 \pm 0.09^{\mathrm{b}}$ & 0.00 \\
\hline a, b. : & &
\end{tabular}

$\stackrel{\mathrm{a}, \mathrm{b}}{\mathrm{b}}$ : Means with the same superscript on the same row are not significantly different $(\mathrm{p}>0.05) . \mathrm{P}=$ probability. $\mathrm{T} 0^{-}=\mathrm{control}$ diet; $\mathrm{T} 0^{+}=\mathrm{T} 0+0.1 \%$ Doxycycline; $\mathrm{T} 1=\mathrm{T} 0+2 \mathrm{~g}$ of Pentadiplandra brazzeana $/ \mathrm{kg}$ of feed; $\mathrm{T} 2=\mathrm{T} 0+2 \mathrm{~g}$ of Pentadiplandra brazzeana/liter of water. 


\section{Biochemical parameters}

Table 5 summarizes the effects of feeding diets of $P$. brazzeana powder on biochemical parameters. With the exception of ASAT and LDL cholesterol which were markedly affected ( $p<0.05)$, experimental diet did not significantly affect the other studied biochemical parameters. Diet receiving antibiotic induced a significant increase in serum level of ASAT ( $<$ 0.05). There were no significant effects between $P$. brazzeana feeding diets and the negative control diet on serum content of ASAT, ALAT, creatinine, urea, total cholesterol, triglycerides and HDL cholesterol. These findings indicated that supplementation of P. brazzeana powder in feed or water had no negative effect on the liver and kidney. This can be due to the presence of hepato-protectory effect of substances present in the studied spice like saponins (Barbosa, 2014). It can be suggested that active compounds have improved the secretion of bile salt and led to a better digestion of lipids present in the feed (Frankic et al., 2009). This finding is in agreement with the finding of Ebile et al. (2018a), who recorded no significant effects on serum biochemical parameters of quails. The present results contradict the findings of Kana et al. $(2017 \mathrm{a}, \mathrm{b})$ who respectively reported a marked $(\mathrm{p}<0.05)$ increased in creatinine content with 0.4\% Dischrotachys glomerata and Afrostyrax lepidophyllus in broiler chickens. Diet receiving antibiotic induced a significant increase in serum content of ASAT. These results are in contradiction with the result of Ali et al. (2007) who reported that the addition of thyme in broiler chickens diet induced a significant decrease in serum total cholesterol.

Table 5. Effects of P. brazzeana feeding diets on serum parameters of broilers chickens

\begin{tabular}{|c|c|c|c|c|c|c|}
\hline \multirow{2}{*}{ Parameters } & \multicolumn{5}{|c|}{ Treatments } & \multirow[b]{2}{*}{$\mathbf{P}$} \\
\hline & $\mathbf{T O}^{-}$ & T0+ & T1 & T2 & SEM & \\
\hline$\overline{\operatorname{ASAT}(\mathrm{U} / \mathrm{I})}$ & $157.60^{b}$ & $221.08^{\mathrm{a}}$ & $124.35^{\mathrm{b}}$ & $106.89^{\mathrm{b}}$ & 12.35 & 0.00 \\
\hline $\operatorname{ALAT}(\mathrm{U} / \mathrm{I})$ & 39.20 & 46.25 & 42.65 & 38.93 & 5.96 & 0.97 \\
\hline Urea (mg/dl) & 0.51 & 0.57 & 0.71 & 0.65 & 0.19 & 0.51 \\
\hline Creatinine (mg/dl) & 1.50 & 1.51 & 1.33 & 1.25 & 0.25 & 0.24 \\
\hline Total cholesterol (mg/dl) & 122.74 & 114.69 & 119.11 & 116.16 & 6.29 & 0.82 \\
\hline Triglycerid (mg/dl) & 85.83 & 86.86 & 89.91 & 89.17 & 5.03 & 0.99 \\
\hline HDL cholesterol (mg/dl) & 119.66 & 125.64 & 113.28 & 133.81 & 5.42 & 0.64 \\
\hline LDL cholesterol (mg/dl) & $26.67^{\mathrm{b}}$ & $53.32^{\mathrm{a}}$ & $33.65^{\mathrm{ab}}$ & $21.91^{\mathrm{b}}$ & 4.55 & 0.04 \\
\hline
\end{tabular}

a, b: Means with the same superscript on the same row are not significantly different (p>0.05). p: probability. T0: control diet; $\mathrm{T} 0^{+}$: $\mathrm{T} 0+0.1 \%$ Doxycycline; T1: T0 $+2 \mathrm{~g}$ of Pentadiplandra brazzeana/kg of feed; T2: T0 $+2 \mathrm{~g}$ of Pentadiplandra brazzeana/liter of water.

\section{Hematological parameters}

Table 6 indicates the effects of $P$. brazzeana feeding diets on hematological parameters of broiler chickens at 49 days of age. Feeding broilers with Pentadiplandra brazzeana powder had no significant effects on blood hematological parameters irrespective of the feeding regime. This result is in agreement with the finding of Zomrawi et al. (2012) who stated no significant effect on $\mathrm{Hgb}, \mathrm{MCV}, \mathrm{MCH}$ and $\mathrm{MCHC}$ in blood of broiler chicken supplemented with different levels of ginger root powder. The present results are in contradiction with the findings of Al-Kassie et al. (2011), who recorded a significant decreased in $\mathrm{WBC}, \mathrm{RBC}, \mathrm{Hgb}$ and $\mathrm{PCV}$ when $0.25 \%, 0.5 \%, 0.75 \%$ and $1 \%$ hot red pepper was incorporated through broiler diet compared to the control diet. Furthermore, Vivian et al. (2015) reported a significant increase in WBC, RBC and Hgb compared to the control treatment when $50 \mathrm{ml}$ ginger, garlic and the combination of the two were incorporated in broiler drinking water.

Table 6. Effects of $P$. brazzeana feeding diets on hematological parameters of broiler chickens

\begin{tabular}{lccccc}
\hline \multirow{2}{*}{ Parameters } & \multicolumn{5}{c}{ Treatments } \\
\cline { 2 - 6 } & $\mathbf{T 0}^{-}$ & T0+ & T1 & T2 & P \\
\hline WBC $\left(\mathbf{1 0}^{\mathbf{3}} / \boldsymbol{\mu l}\right)$ & $83.83 \pm 7.36$ & $86.57 \pm 5.97$ & $82.98 \pm 5.45$ & $82.27 \pm 4.65$ & 0.85 \\
RBC $(\mathbf{1 0 6} / \boldsymbol{\mu l})$ & $2.43 \pm 0.24$ & $2.88 \pm 0.40$ & $2.60 \pm 0.28$ & $2.56 \pm 0.15$ & 0.09 \\
Hgb (g/d) & $11.70 \pm 1.14$ & $13.17 \pm 1.75$ & $12.60 \pm 1.14$ & $11.87 \pm 0.72$ & 0.35 \\
PCV (\%) & $33.23 \pm 2.18$ & $37.37 \pm 4.97$ & $33.88 \pm 3.39$ & $33.80 \pm 2.38$ & 0.15 \\
MCV (fL) & $137.43 \pm 4.96$ & $130.17 \pm 6.43$ & $131.10 \pm 5.25$ & $132.47 \pm 5.99$ & 0.35 \\
MCH (pg) & $48.07 \pm 1.64$ & $45.67 \pm 1.79$ & $48.70 \pm 4.40$ & $46.40 \pm 1.86$ & 0.84 \\
PLT $(\mathbf{1 0} / \boldsymbol{\mu l})$ & $47.17 \pm 21.37$ & $51.00 \pm 22.14$ & $46.40 \pm 18.67$ & $37.00 \pm 11.71$ & 0.67 \\
\hline
\end{tabular}

\section{CONCLUSION}

It's concluded that dietary administration of $P$. brazzeana powder to through drinking water at level of $2 \mathrm{~g} / \mathrm{L}$ improved growth performances of broiler chickens. Hence, P. brazzeana powder could be used through water as alternative to antibiotics growth promoters in poultry production. 


\section{DECLARATIONS}

\section{Competing interests}

The authors declare that they have no competing interests.

\section{Author's contribution}

Necdem T. Boris, Donfack Mikael, Deffo T. Gilchrist and Kengni N. Josiane went to the field to carry out the research and collect the samples. Kana J. Raphaël and Ngouana T. Ruben supervised the overall research work. Necdem T. Boris wrote the first draft before being revised by Kana J. Raphaël and Ebile D. Agwah. The final draft of article is approved by all the authors.

\section{Consent to publish}

All persons gave their informed consent prior to their inclusion in the study.

\section{REFERENCES}

Abdou Bouba A, Njintang YN, Foyet H, Scher J, Montet D and Mbofung C (2012). Proximate composition, mineral and vitamin content of some wild plants used as spices in Cameroon. Food and Nutrition Sciences, 3 (4): 423-432. DOI: http://www.doi.org/10.4236/fns.2012.34061

Ali MN, Hassan MS and Abdel-Ghany FA (2007). Effect of strain, type of natural antioxydant and sulphate on productive, physiological and hatching performance of native laying hens. International Journal of Poultry Science, 6: 539-554. DOI: http://www.doi.org/10.3923/ijps.2007.539.554

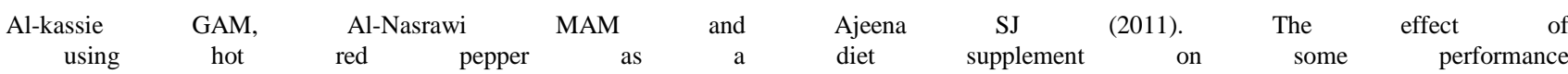
traits in broilers. Pakistan Journal of Nutrition, 10: 842-845. DOI: http://www.doi.org/10.3923/pjn.2011.842.845

Alloui MN, Ben Aksa SN and Ibri F (2011). Utilisation of fenugreek (Trigonella foenum-graecum) as growth promoter for broiler chickens. Journal of World's Poultry Research, 2: 25-27. Available https://www.researchgate.net/profile/Nadir_Alloui/publication/225037679/links/0912f4fbe5e9590d55000000/.pdf

Alonge EO, Eruvbetine D, Idowu OMO, Obadina AO and Olukomaiya OO (2017). Effect of dietary feed additives on haematological and serum biochemical parameters of broiler chickens. Online Journal of Animal and Feed Research, 7(1): 18-23. Available at: http://www.ojafr.ir/main/attachments/article/125/OJAFR\%207(1)\%2018-23,\%202017.pdf

Barbosa ADP (2014). An overview on the biological and pharmacological activities of saponins. International Journal of Pharmacy and Pharmaceutical Sciences, 6 (8): 47-50. DOI: http://www.doi.org/10.5897/AJPP2014.4136

Cervantes H (2006). The future of antibiotic growth promoters in poultry production._International Journal of Poultry Science, 45: 14-15. Available at: http://www.facta.org.br/wpc2012-cd/pdfs/plenary/Hector_M._Cervantes.pdf

Cimanga KR, Lubiba NZ, Makila BMF, Tona LG, Kambu KO, Vlietinck AJ and Pieters L (2018). Biological activities of Arredoul Jaune, a phytomedicine based ethanol extract from fresh roots of Pentadiplandra brazzeana Baill. (Pentadiplandaceae) used as an antidiarrhoeal drug in Kisangani-Democratic Republic of Congo. European Journal of Biomedical and Pharmaceutical Sciences, 5(1): 130-139. Available at: https://doc.anet.be/docman/docman.phtml?file=.irua.881bdf.148059.pdf

Dzoyem JP, Tchuenguem RT, Kuiate JR, Teke GN, Kechia FA, and Kuete V (2014). In Vitro and In Vivo antifungal activities of selected Cameroonian dietary spices. BMC Complementarry and Alternative Medicine, 14: 58. DOI: https://www.doi.org/10.1186/1472-6882-14-58

Ebile DA, Kana JR, Pimagha MHJ, Edie NLW, Nguefack DG, Ngouana TR and Fonteh AF (2018a). Effects of Dichrostachys Glomerata Feeding Regimes on Growth Performance, Gut Microbiota and Haemato-Biochemical Profile of Japanese Quails. Journal of Animal Research and Nutrition 3(2): 5. DOI: http://www.doi.org/10.21767/2572-5459.100049

Elaroussi MA, Mohamed MS, El-Barkouki EM, Abdou AM and Hatab MH (2008). Ochratoxicosis in Broiler Chickens: Functional and Histological Changes in Target Organs. International Journal of Poultry Science, 7 (5): 414-422. Available at: http://www.docsdrive.com/pdfs/ansinet/ijps/2008/414-422.pdf

Fankam AG, Kuete V, Voukeng IK, Kuiate JR and Pages JM (2011). Antibacterial activities of selected Cameroonian spices and their synergistic effects with Antibiotics against multidrug-resistant phenotypes. BMC Complementary and Alternative Medicine, 11: 140. DOI: https://doi.org/10.1186/1472-6882-11-104

Frankic T, Voljg M, Salobir J and Rezar V (2009). Use of Herbs and spices and their extracts in animal nutrition. Acta Agriculturae Slovenica, 92(2): 95-102. Available at: http://aas.bf.uni-lj.si/zootehnika/94-2009/PDF/94-2009-2-95-102.pdf

Gakunga JN, Mirianga B, Muwonge H, Sembajwe LF and Kateregga J (2013). Antidiarrheal activity of ethanolic fruit extract of Psidium guayava in castor oil induced diarrhea in albino rats. National Journal of Physiology and Pharmacology, 3(2): 191-197. DOI: http://www.doi.org/10.5455/njppp.2013.3.100620131

Goodarzi M and Shahram N (2014). Effect of onion extract in drink water on performance and carcass traits in broiler chickens. IERI Procedia, 8: 107112. DOI: https://doi.org/10.1016/j.ieri.2014.09.018

Guo FC, Williams BA and Kwakkel PR (2004). Effects of mushroom and herb polysaccharides, as alternative for an antibiotic on the cecal microbial ecosystem in broiler chickens. Poultry Science, 83: 175-182. DOI: https://doi.org/10.1093/ps/83.7.1124

Harborne JB (1973): Phytochemical Methods. New York, Chapman and Hall.

Kana JR, Mube KH, Ngouana TR, Komguep R, Yangoue A, Tsafong F and Teguia A (2017c). Growth performances and serum biochemical response of broiler chickens fed on diet supplemented with Tetrapleura tetrapleura fruit powder as substitute to antibiotic growth promoters. International Journal of Innovation and Applied studies, $\quad 21(1)$ : 68-76. https://search.proquest.com/openview/afa67b5f2f702bbfa82418100a5811f1/

Kana JR, Mube KH, Ngouana TR, Tsafong F, Komguep R, Yangoue A and Teguia A (2017a). effect of dietary mimosa small bell (Dichostachys glomerata) fruit supplement as alternative to antibiotic growth promoter for broiler chicken. Journal of World`s Poultry Research, 7(1): 27-34. Available at: http://jwpr.science-line.com/attachments/article/40/J\%20World\%20Poult\%20Res\%207(1)\%2027-34,\%202017.pdf 
Kana JR, Mube KH, Ngouana TR, Yangoue A, Komguep R, Tsafong F and Teguia A (2017b). Growth Performance and Serum Biochemical Profile of Broiler Chickens Fed on Diets Supplemented with Afrostyrax lepidophyllus Fruit and Bark as Alternative to Antibiotic Growth Promoters. Journal of Veterinary Medicine Research, 4(6): 1095. Available at https://www.jscimedcentral.com/VeterinaryMedicine/veterinarymedicine-41095.pdf

Karangiya VK, Savsani HH, Patil SS, Garg DD, Murthy KS, Ribadiya NK and Vekariya SJ (2016). Effect of dietary supplementation of garlic, ginger and their combination on feed intake, growth performance and economics in commercial broilers, Veterinary World, 9(3): 245-250. DOI: https://doi.org/10.14202/vetworld.2016.245-250

Kouka, LA. (2001). Biotopes et diversité des groupes phytogéographiques dans la flore du Parc National d'Odzala (Congo-Brazzaville). Bulletin du Jardin Botanique National de Belgique, 827-835. Available at :https://www.jstor.org/stable/3668721

Kuete V, Kruche B, Youns M, Voukeng I, Fankam A, Tankeo S, Lacmata S, and Efferth T (2011). Cytotoxicity of some Cameroonian spices and selected medicinal plant extracts. Journal of Ethnopharmacology 134: 803-812.DOI: https://doi.org/10.1016/j.jep.2011.01.035

Lautenschläger T, Monizi M, Pedro M, Bránquima MF, Heinze C, and Neinhuis C (2018)First large-scale ethnobotanical survey in the province of Uíge, northern Angola. Journal of Ethnobiology and Ethnomedicine, 14(1): 51. DOI: https://doi.org/10.1186/s13002-018-0238-3

Mahmood H, Ghorbanali S and Ahmad K (2018). Comparative effects of powder, aqueous and methanolic extracts of purslane (Portulaca oleracea L.) on growth performance, antioxidant status, abdominal fat deposition and plasma lipids in broiler chickens. Animal Production Science, 59: 89100. DOI: https://doi.org/10.1071/AN17352

Muanda F, Kone D, Dicko A, Soulimani R and Younos C (2011). Phytochemical composition and antioxydant Capacity of Three Malian Medicinal Plant Parts. Compilation of Alternative Medecine, 8: Article ID 674320. DOI:https://doi.org/10.1093/ecam/nep109

Ngbolua KN, Rafatro H, Rakotoarimanana H, Ratsimamanga US, Mudogo V, Mpiana PT and Tshibangu DST (2011). Pharmacological screening of some traditionally-used antimalarial plants from the Democratic Republic of Congo compared to its ecological taxonomic equivalence in Madagascar. International Journal of Biological and Chemical Sciences, 5 (5): 1797-1804. DOI: https://doi.org/10.4314/ijbcs.v5i5.3

Ngouana TR, Kana JR, Necdem TB, Yemdjie MDD and Mube KH (2017). Performances of Broiler Chickens Fed on Diet Supplemented with Thyme and Oregano essential Oils Stabilized in a Plant Charcoal Matrix. Journal of World Poultry Research, 7: 79-87. Available at: http://jwpr.scienceline.com/attachments/article/41/J\%20World\%20Poult\%20Res\%207(2)\%2079-87,\%202017.pdf

Nweze BO, Nwankwegu AE and Ekwe OO (2011). The performance of the broilers chickens on African Porridge fruit (Tetrapleura tetraptera) Pod under different feeding regimes. Asian Journal of Poultry Science 5: 144-149. DOI: https://doi.org/10.3923/ajpsaj.2011.144.149

Nyegue M, Ndoyé F, Amvam Zollo H, Etoa FX, Agnaniet H, and Menut C (2009). Chemical and biological evaluation of essential oil of Pentadiplandra brazzeana (Bail.) roots from Cameroon. Advance Phytotherapy Research, 91-107.

Oko OOK, and Agiang EA (2009). Phytochemical evaluation of 3 extractants of Aspilla Africana leaves. Proceeding of the international conference on Global food crisis, April 19-24 ${ }^{\text {th }}$, FUT, Owerri, Nigeria, pp. 87-90.

Steel, RGD. and Torri JH. (1980). Principles and procedures of statistics: A Biometrical Approach.2nd ed. McGraw Hill, Kogakusha Ltd, Tokyo.

Toghyani M, Gheisari A, Ghalamkari G, and Eghbalsaied S (2011). Evaluationm of cinnamon and garlic as antibiotic growth promoter substitutions on performance, immune responses, serum biochemical and haematological parameters in broiler chicks. Livestock Science, 167-173. DOI: https://doi.org/10.1016/j.livsci.2010.12.018

Vicente JL, Avina L, Torres-Rodriguez A, Hargis B, and Tellez G (2007). Effect of a Lactobacillus spp-based probiotic culture product on broiler chick performance under commercial conditions. International Journal of Poultry Science, 6 (3): 154-156. DOI: http://www.doi.org/10.3923/ijps.2007.154.156

Vivian UO, Harriet MNF, Solomon OO and Joesph OU (2015). Evaluation of Growth Performance, Haematological and Serum Biochemical Response of Broiler Chickens to Aqueous Extract of Ginger and Garlic. Journal of Agricultural Science, 7: 167-173. Available at: http://citeseerx.ist.psu.edu/viewdoc/download?doi=10.1.1.903.2157\&rep=rep1\&type=pdf

Windisch WM, Schedle K, Plitzner C and Kroismayr A (2008). Use of phytogenic products as feed additives for swine and poultry. Journal of Animal Science. 86: 140-148. PMID: 18073277

Zomrawi WB, Abdel Atti KHA and Dousa BM (2012). The effect of ginger root powder (Zingiber officinale) supplementation on broiler chicks performance, blood and serum constituents. Online Journal of Animal Feed Research, 2(6): 457-460. Available at: http://www.scienceline.com/index/; http://www.ojafr.ir 